\title{
Socio-economic Background and Women Empowerment in Cross River State, Nigeria: Implications for Maternal Health, Using Data from the NDHS 2008
}

\author{
David B. Ugal \\ Department of Sociology, Federal University, Nigeria
}

Copyright $(2015$ by authors, all rights reserved. Authors agree that this article remains permanently open access under the terms of the Creative Commons Attribution License 4.0 International License

\begin{abstract}
Gender equality and women's empowerment are important indicators in development strategies that focus on poverty reduction and improved maternal health. Despite the importance of these factors to the overall wellbeing of women and the nation, research in this area is neglected. Besides the condition of women in relation to women empowerment, indicators have remained poor in the study area. The study used data from the 2008 national Demographic and Health Survey (NDHS, 2008) to examine the socio-economic condition of women in relation to their level of empowerment and how it affects maternal health outcome in Cross River State. The study utilized data of a representative sample of 735 women of age 15-49. A majority of respondents reported Poor/low socio-economic status ranging from low educational status, unskilled occupation, and low income per month, seasonal employment etc. This affected the level of empowerment in all the indicators - women's participation in household decision making, their attitude towards wife beating and their attitude towards a wife's right to refuse sexual intercourse with her husband or partner. These conditions manifest in high maternal morbidity and mortality. These are also responsible for women's inability to determine number of children, spacing and antenatal care options available to them. These findings are in line with the prevalent scenario in the entire country. There is therefore an urgent need for improving and enhancing women socio-economic condition as it will improve their level of empowerment and will bring about better maternal health status.
\end{abstract}

Keywords Socio Economic Status, Women Empowerment, Maternal Health

\section{Background/Statement of the Problem}

Women's empowerment is a very crucial and important factor in determining maternal health, poverty reduction, improved standard of living and good governance. In June, 2007 the Federal Government of Nigeria launched the National Gender Policy to promote gender equity and sustainable development. The policy derives essentially from the Constitution of the Federal Republic 1999 which guarantees the fundamental human rights of all its citizens and incorporates the principles of global and regional framework that support equity and women empowerment.

The condition of Nigerian women however, shows that they are not often privileged because they often have more difficulty accessing public services such as health care, water supply, sanitation and education. Meanwhile, these are prerequisites for women empowerment and development. Women are often under-represented in public administration, particularly in senior positions. They do not have real voice in most governance institutions from the judiciary to the civil service ${ }^{1}$.

In the face of all these, the condition of women especially maternal health is worsening. ${ }^{1}$ Posits that Nigeria has one of the worst health indicators in the world as evidenced by its health system performance ranking 187 among 191 member states.

${ }^{2}$ Indicated that there are 11,000 maternal deaths for every 100,000 live births in Nigeria. It further estimated that every year 59,000 Nigerian women die in child birth - the second (after India). For every woman that dies of pregnancy complications, over twenty suffer lifelong disabilities. The majority of these deaths, as in the rest of the world are preventable though the casual factors may be multiple and complex, however, government must be held accountable when its actions and inactions contribute to this ongoing loss of women's lives ${ }^{1}$

It should be recognized that there are several obstacles standing in the way of women gaining access to maternal health facilities, the most significant being inequality with respect to access to education, discrimination in educational opportunities, employment and occupation, which leads to categorization of jobs according to gender. There is also inequality with respect to access to factors of production, low level of women's participation in decision-making and social 
control over their bodies and finally, social attitudes ${ }^{1}$

The female demographic and socio-economic profile is essential for the interpretation of the findings on the empowerment of women. The basic background characteristics - age, educational attainment, literacy, employment, occupation etc are crucial to determining their relative effect on the ability of women to take decision that approximates or are indications for women empowerment.

The condition of women leaves much to be desired and it is therefore necessary to assess their present level of empowerment. This is with a view to finding out the confounding effects of socio-demographic status on their level of empowerment as a correlate for maternal health in Cross River State using the NDHS 2008 data.

The paper generally assesses the socio-economic characteristics of women as a correlate to their empowerment and implication for maternal health. Specifically - the paper sought to: Identify women's socio-economic status, determine their employment status, examine their control over their earnings, explore their participation in decision making as indicators for empowerment and relate these to maternal health.

\section{Methodology}

The study utilizes data from the National Demographic Health Survey ${ }^{3}$. The survey used a nationally representative sample of more than 36,000 households. All women age 15-49 in these households were individually interviewed. The survey provides an updated estimate of basic demographic and health indicators. The sample was designed to provide population and health indicators at the national, zonal and state levels. It also allowed for specific indicators.

Questionnaires were used for the survey. From this design, the data relating to Cross River State in relation to women empowerment and socio-economic status were isolated and used for the analysis. The frequencies of empowerment indicators were presented and the Pearson Moment Product of Correlation Coefficient was used in examining relationship between women socio-economic status and development indicators. This was done with a view to identifying the degree of empowerment of women showing implications for maternal health in the state.

\section{Results}

Table one above presents data on socio-economic status of women in Cross River State. The table shows that almost 34 percent of women in the state have some secondary school level education though below national figures of $35 \%$, yet it depict a comparatively educated population. These have implication for women acting as change agent. The employment status of women shows that 69.8 percent of women are currently employed but almost 30 percent have not been employed in the last 12 months preceding the survey. This is an indication that a considerate number of women are unemployed. Only 5.4 percent of women are skilled professionals and managerial category of occupation while almost 60 percent are employed in the agricultural sector. This is very instructive as agriculture is the highest employment of labour generally and women particularly in Nigeria. Over 60 percent of the women earn nothing. This is because they engage in subsistent agriculture usually to feed their families hence do not get paid for it. This explains the high level of poverty as women really do not generate anything at the end of each month. Only about 30 percent earn some cash at the end of the month. The condition of women is therefore generally poor and dependent on the men for their survival.

Table 1. Socio-demographic characteristics of women

\begin{tabular}{|c|c|c|c|}
\hline Categories & No & $\%$ & Total \\
\hline \multicolumn{4}{|l|}{ Educational Attainment } \\
\hline No education & 63 & 8.5 & 735 \\
\hline Some primary & 63 & 8.5 & 735 \\
\hline Completed primary & 155 & 20.9 & 735 \\
\hline Some secondary & 225 & 30.5 & 735 \\
\hline Complete secondary & 155 & 21.5 & 735 \\
\hline \multirow[t]{2}{*}{ More than secondary } & 74 & 10.1 & 735 \\
\hline & 175 & $100 \%$ & \\
\hline \multicolumn{4}{|l|}{ Employment status } \\
\hline Currently employed & 513 & 69.8 & 735 \\
\hline Not currently employed & 16 & 2.2 & 735 \\
\hline $\begin{array}{l}\text { Not employed in the } 12 \text { months } \\
\text { preceding survey }\end{array}$ & 205 & 27.9 & 735 \\
\hline \multirow[t]{2}{*}{ Missing } & 1 & 0.1 & 735 \\
\hline & 735 & 100 & \\
\hline \multicolumn{4}{|l|}{ Occupation } \\
\hline Professional/technical/managerial & 29 & 5.4 & 530 \\
\hline Clerical & 8 & 1.1 & 530 \\
\hline Sales and services & 37 & 26.1 & 530 \\
\hline Skilled manual & 36 & 6.7 & 530 \\
\hline Unskilled manual & 1 & 0.2 & 530 \\
\hline Agriculture & 316 & 59.8 & 530 \\
\hline Missing & 3 & 0.7 & 530 \\
\hline \multicolumn{4}{|l|}{ Type of economic } \\
\hline Cash only & 158 & 29.9 & 530 \\
\hline Cash and in kind & 27 & 5.0 & 530 \\
\hline In kind only & 7 & 1.3 & 530 \\
\hline Not paid & 338 & 63.8 & 530 \\
\hline Missing & 530 & 100 & \\
\hline \multicolumn{4}{|l|}{ Type of employment } \\
\hline Family members & 90 & 17.0 & 530 \\
\hline Non family member & 65 & 12.3 & 530 \\
\hline Self-employed & 374 & 70.5 & 530 \\
\hline Missing & 11 & 0.2 & 530 \\
\hline \multicolumn{4}{|l|}{ Continuity of employment } \\
\hline All year & 285 & 53.7 & 530 \\
\hline Seasonal & 201 & 38.0 & 530 \\
\hline Occasional & 41 & 7.7 & 530 \\
\hline Missing & 3 & 0.5 & 530 \\
\hline
\end{tabular}

Over 70 percent of the respondents are self-employed. This is an indication that since they are engaged in agriculture, they also earn little or nothing and this is usually in their own farms which make them self-employed. This depicts them as working only during seasons that favour agricultural activities. However, about 38 percent of the women are employed all year round. 


\section{Women Empowerment}

According to $^{3}$, there are three sets of empowerment indicators. These are women's participation in household decision making, their attitude towards wife beating and their attitude towards a wife's right to refuse sexual intercourse with her husband or partner. This is summarized in three separate indices. The first index shows the number of decision in which women participate either alone or jointly with their husbands or partners. This index ranges from 0 to 4 and is positively related to women's empowerment. It reflects the degree of decision making control that women are able to exercise in areas that affect their own lives.

The second index which ranges from 0 to 5 is the number of reasons for which a women thinks that a husband is justified in beating his wife. A lower score on this indicator is interpreted as reflecting a greater sense of entitlement and self-esteem and higher status of women. All these are indicative of women empowerment.

The final index, which ranges in value from 0 to 3 , is the number of circumstances in which the respondent feels that a woman is justified in refusing sexual intercourse with her husband or partner. This indicator reflects perceptions of sexual roles and women's right over their bodies and relates positively to women's sense of self and empowerment.

Apart from these, women's control over their own earnings was identified. This is because it is a means of assessing women's autonomy and data on how much they earned from their work in the 12 months preceding the survey and how or who decides how these earnings are spent were identified. This is because employment and earnings are more likely to empower women if women themselves control their own earnings.

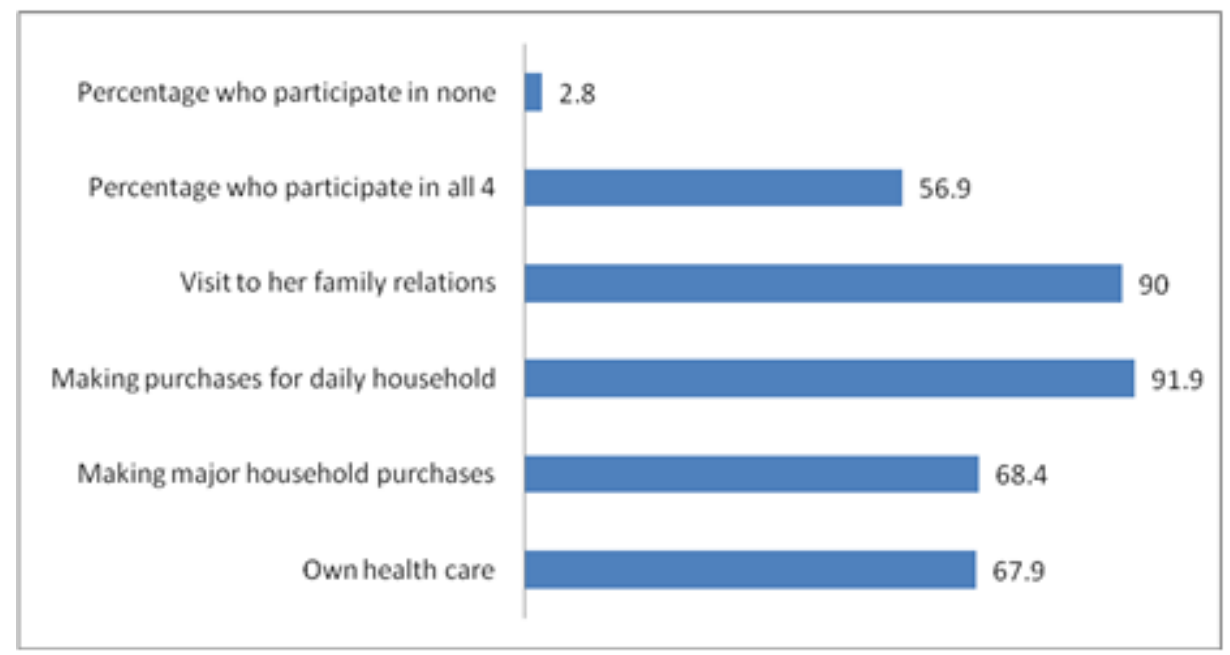

Figure 1. Chart for women's participation in decision-making in Cross River State

The ability of women to make decisions that affect their personal circumstances is essential for their empowerment. From the four types of questions displayed in the chart above indicates that women took relatively crucial part in household decision-making. This is because in all the four types of questions, women took part in up to 60 percent and above in decision making and only about 2 percent did not take part in all decisions.

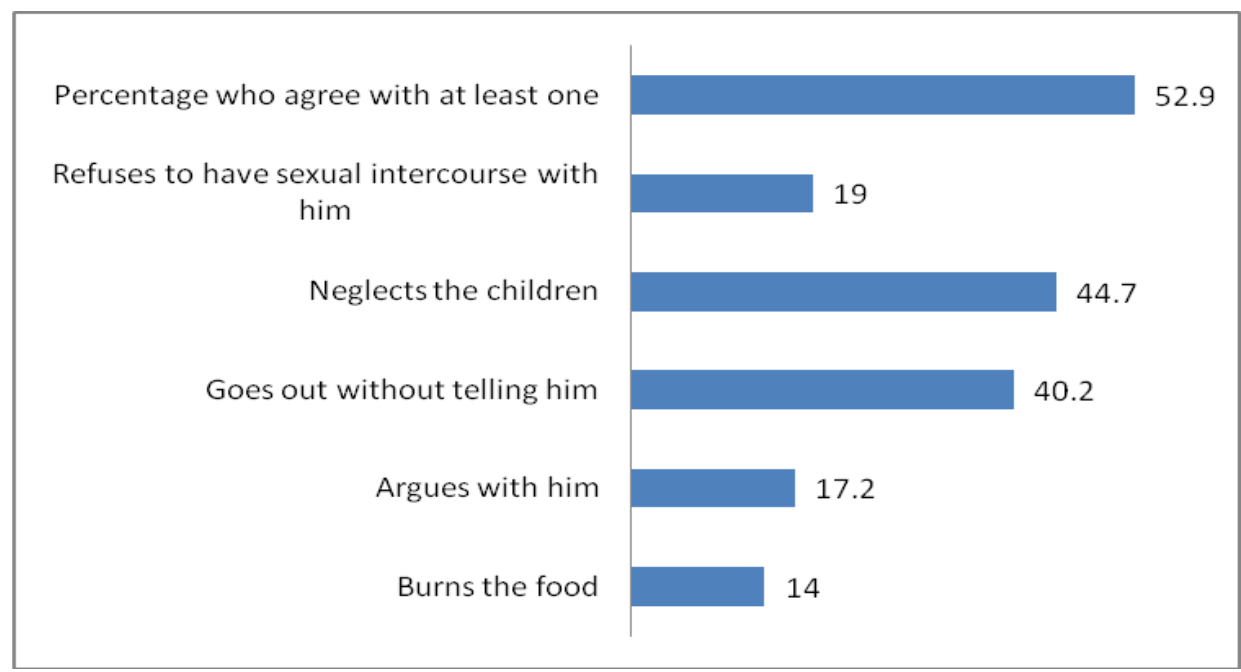

Figure 2. Chart for women who agree that man/husband is justified in beating his wife for specific reasons 
The second chart above showed that more than half of the women justify husband's beating of wife for specific reasons. But, over 40 percent agree that a husband can hit or beat his wife if she neglects the children while 14 percent agree that if she burns the food, she should be beaten. This finding is instructive as it shows the women's self-worth and self-esteem. It shows that they have low self-worth and esteem. This is because a man should not physically assault his wife for any reason.

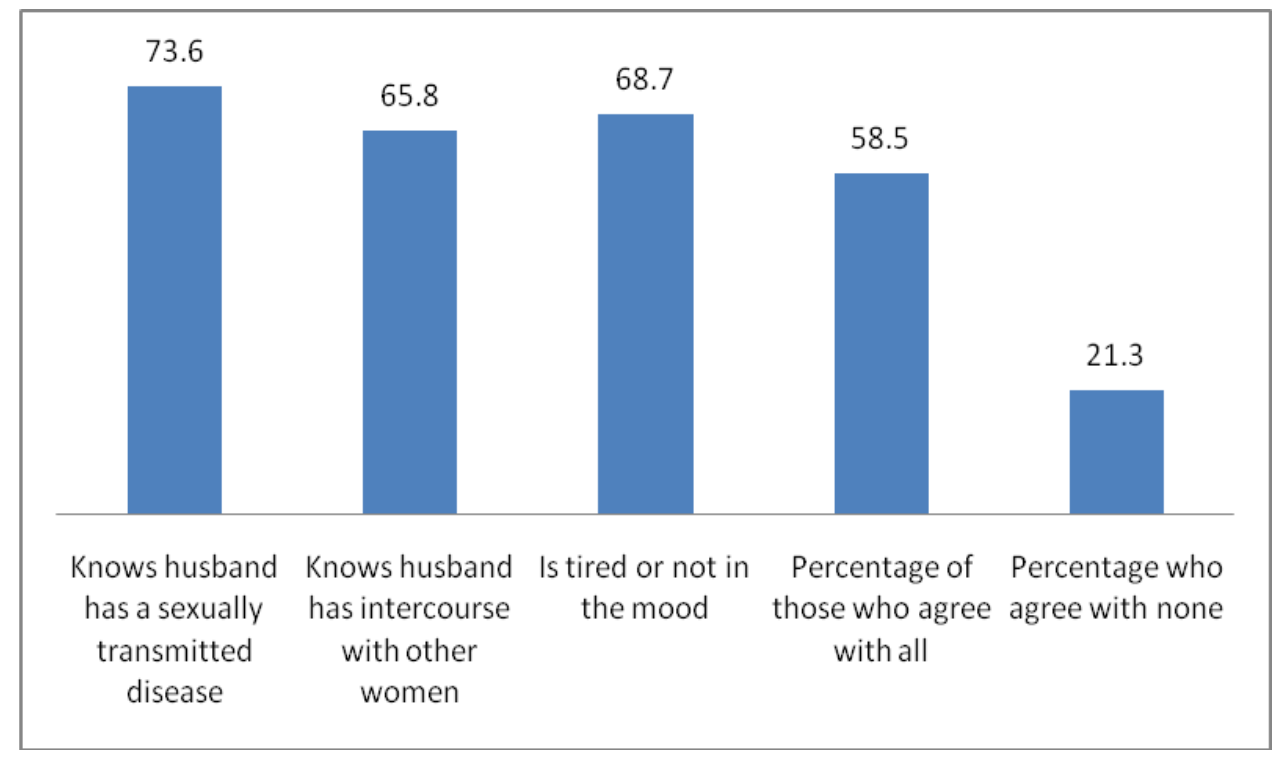

Figure 3. Chart for women who believe that a wife is justified in refusing to have sexual intercourse with her husband in specific circumstances

The justification for refusing sexual intercourse with husband is instructive as more than half of the women agreed that women are justified in all cases to refused sex with their husbands but for refusing to have sex with husband when it is known that he has an infection has the highest percentage. This depicts that the women are abreast with what is going on in relation to infection.

Table 5. Percentage distribution of women who decides on how wife's cash earnings are used

\begin{tabular}{cccc}
\hline Persons who decides how wife's earnings are used & No & $\%$ & Total \\
\hline Mainly wife & 39 & 31.1 & 126 \\
Wife and husband jointly & 73 & 58.3 & 126 \\
Mainly husband & 10 & 8.3 & 126 \\
Others & - & 0.0 & 126 \\
Missing & 3 & 2.3 & 126 \\
Women's cash earnings compared with husband's cash & & & \\
earnings & & & 126 \\
More & 11 & 8.4 & 126 \\
Less & 15 & 12.0 & 126 \\
About the same & 21 & 16.6 & 126 \\
Husband/partner has no earnings & 1 & 0.8 & 126 \\
Do not know/missing & 3 & 2.3 &
\end{tabular}

Joint decision is the commonest feature in the table above. It is known that this situation brings both husband and wife together and often look at themselves with respect. This is some form of empowerment. 


\section{Bivariate Analyses}

Educational level and Women Empowerment

\begin{tabular}{|c|c|c|c|c|}
\hline \multirow[t]{2}{*}{ Educational level } & \multicolumn{3}{|c|}{ Employment Status } & \multirow{2}{*}{ Total } \\
\hline & All year & Seasonal & Occasional & \\
\hline No Education & $33(56.9 \%)$ & $25(43.1 \%)$ & $0(0.0 \%)$ & $58(100.0 \%)$ \\
\hline Primary & $90(50.3 \%)$ & $82(45.8 \%)$ & $9(3.9 \%)$ & $179(100.0 \%)$ \\
\hline Secondary & $130(53.5 \%)$ & $84(34.6 \%)$ & $29(11.9 \%)$ & $234(100.0 \%$ \\
\hline Higher & $32(66.7 \%)$ & $11(22.7 \%)$ & $5(10.4 \%)$ & $48(100.0 \%)$ \\
\hline Total & $285(54.0 \%)$ & $202(38.3 \%)$ & $41(7.7 \%)$ & $528(100.0 \%)$ \\
\hline
\end{tabular}

Educational Level And Household Decision(how to spend own earnings)

$\begin{array}{ccccc}\text { Educational level } & \text { Myself } & \text { Jointly } & \text { Husband } & \text { Total } \\ \text { No Education } & 2(16.7 \%) & 9(75.0 \%) & 1(8.3 \%) & 12(100.0 \%) \\ \text { Primary } & 10(28.6 \%) & 25(71.4 \%) & 0(0.0 \%) & 35(100.0 \%) \\ \text { Secondary } & 17(30.4 \%) & 33(58.9 \%) & 6(10.7 \%) & 56(100.0 \%) \\ \text { Higher } & 10(47.6 \%) & 7(33.3 \%) & 4(19.0 \%) & 21(100.0 \%) \\ \text { Total } & 39(31.5 \%) & 74(59.7 \%) & 11(8.9 \%) & 533(100.0 \%)\end{array}$

$\mathrm{X}^{2}=12.197, \mathrm{DF}=6, \mathrm{p}<.05=.020$

Educational Level and Household Decision(final say on own Health)

$\begin{array}{ccccc}\text { Educational Level } & \text { Myself } & \text { Jointly } & \text { Husband } & \text { Total } \\ \text { No edu } & 10(18.9 \%) & 29(54.7 \%) & 14(26.4 \%) & 53(100 \%) \\ \text { Primary } & 14(9.2 \%) & 85(55.6 \%) & 54(35.3 \%) & 153(100 \%) \\ \text { Secondary } & 18(10.84 \%) & 96(57.5 \%) & 53(31.7 \%) & 167(100 \%) \\ \text { Higher } & 7(22.6 \%) & 18(58.1 \%) & 6(19.4 \%) & 31(100 \%) \\ \text { Total } & 49(12.0 \%) & 228(56.4 \%) & 127(31.4 \%) & 404(100 \%)\end{array}$

$X^{2}=8.836, d f=6, p<.05=.216$

Educational qualification and Household Decision( final say on household purchases)

$\begin{array}{ccccc}\text { Educational level } & \text { Myself } & \text { Joint } & \text { Husband } & \text { Total } \\ \text { No edu } & 8(14.8 \%) & 23(42.6 \%) & 23(42.6 \%) & 54(100.0 \%) \\ \text { Primary } & 9(5.9 \%) & 94(61.4 \%) & 50(32.7 \%) & 153(100.0 \%) \\ \text { Secondary } & 13(7.8 \%) & 108(64.7 \%) & 46(27.5 \%) & 167(100.0 \%) \\ \text { Higher } & 6(19.4 \%) & 18(58.1 \%) & 7(22.4 \%) & 31(100.0 \%) \\ \text { Total } & 36(8.9 \%) & 234(60.0 \%) & 126(31.1 \%) & 405(100.0 \%)\end{array}$

$$
\mathrm{X}^{2}=6.788, \mathrm{DF}=6, \mathrm{P}<.05=.324
$$

Educational qualification and Household Decision(final say on visit to relatives)

$$
\begin{array}{cccc}
\text { Educational level } & \text { Myself } & \text { Joint } & \text { Husband } \\
\text { No edu } & 20(37.0 \%) & 29(53.7 \%) & 5(9.3 \%) \\
\text { Primary } & 19(12.4 \%) & 118(77.1 \%) & 16(10.5 \%) \\
\text { Secondary } & 32(19.2 \%) & 124(74.3 \%) & 11(6.6 \%) \\
\text { Higher } & 7(22.6 \%) & 19(61.3 \%) & 5(16.1 \%) \\
\text { Total } & 78(19.3) & 200(71.6 \%) & 37(9.1 \%) \\
& \mathbf{X}^{2}=\mathbf{1 9 . 5 9 0}, \mathbf{D F}=\mathbf{6}, \mathbf{P}<. \mathbf{0 5}=\mathbf{. 0 0 6}
\end{array}
$$

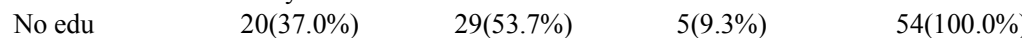

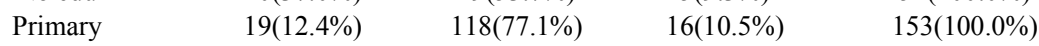

$\begin{array}{cccc}\text { Secondary } & 32(19.2 \%) & 124(74.3 \%) & 11(6.6 \%) \\ \text { Higher } & 7(22.6 \%) & 19(61.3 \%) & 5(16.1 \%)\end{array}$

$167(100.0 \%)$

$31(100.0 \%)$

$405(100.0 \%)$

\begin{tabular}{|c|c|c|c|c|}
\hline \\
\hline Educational level & No & Yes & Don't know & Total \\
\hline No edu & 48(77.4\%) & $8(12.9 \%)$ & $6(9.7 \%)$ & $62(100.0 \%)$ \\
\hline Primary & $158(73.5 \%)$ & $45(20.9 \%)$ & $12(5.6 \%)$ & $215(100.0 \%)$ \\
\hline Secondary & $292(76.4 \%)$ & $68(17.8 \%)$ & $22(5.8 \%)$ & $382(100.0 \%)$ \\
\hline Higher & $65(87.8 \%)$ & $68(17.8 \%)$ & $22(5.8 \%)$ & $383(100.0 \%)$ \\
\hline Total & $563(76.8 \%)$ & $127(17.3 \%)$ & $43(5.9 \%)$ & $733(100.0 \%)$ \\
\hline \multicolumn{5}{|c|}{$\mathrm{X}^{2}=9.468, \mathrm{DF}=6, \mathrm{P}<.05=.121$} \\
\hline cational qualif & 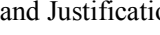 & & & \\
\hline Educational level & No & Yes & Don't know & Total \\
\hline No edu & $47(75.8 \%)$ & $12(19.4 \%)$ & $3(4.8 \%)$ & $62(100.0 \%)$ \\
\hline Primary & $151(70.2 \%)$ & $5023.3 \%)$ & $14(6.5 \%)$ & $215(100.0 \%)$ \\
\hline Secondary & $284(74.2 \%)$ & $71(18.5 \%)$ & $28(7.3 \%)$ & $383(100.0 \%)$ \\
\hline Higher & $65(87.8 \%)$ & $6(8.1 \%)$ & $3(4.1 \%)$ & $74(100 \%)$ \\
\hline Total & $547(74.5 \%)$ & $139(18.9 \%)$ & $48) 0.5 \%)$ & $734(100.0 \%)$ \\
\hline
\end{tabular}

Educational qualification and Justification for beating wife(neglect children)

\begin{tabular}{cccc} 
Educational level & No & Yes & Don't know \\
No edu & $34(54.0 \%)$ & $28(44.4 \%)$ & $1(1.6 \%)$ \\
Primary & $116(53.7 \%)$ & $98(45.4 \%)$ & $2(.9 \%)$ \\
Secondary & $198(51.7 \%)$ & $181(47.3 \%)$ & $4(1.0 \%)$ \\
Higher & $50(67.6 \%)$ & $23(31.1 \%)$ & $1(1.4 \%)$ \\
Total & $398(54.1 \%)$ & $33(44.8 \%)$ & $8(1.1 \%)$ \\
\multicolumn{2}{c}{$\mathbf{X}^{\mathbf{2}}=\mathbf{6 . 7 8 8}, \mathbf{D F}=\mathbf{6}, \mathbf{P}<. \mathbf{0 5}=\mathbf{. 3 2 4}$}
\end{tabular}

Educational qualification and Justification for beating wife (Argue with him) 
The table above involves the bivariate analysis of data whose frequency is shown above. The data showed that the educational qualification of women play a very vital and dominant role in the level of their empowerment. Women with higher educational qualification are more likely to work all year round compared with those who had no education and primary level. There is also a significant relationship between educational qualification and enhanced employment status.

Decision in relation to how women spend their earnings is crucially influenced by educational status. Women with higher educational level single-handedly took decisions on the spending of their earnings while those with no education and primary educational level jointly took decisions on how to spend their earnings. The effect of educational qualification also influenced decision on own health and purchases for the house. The lesser women are educated, the more they justify wife beating the reverse is the case. This is because almost 70 percent of women with higher educational level do not justify wife beating for any reason. This finding is also applicable to when wife argues with husband, refuse to have sex with him and burns food. The table also shows that the higher women are educated, the better they are likely to refuse sex with their husband under different circumstances.

\section{Discussion of Findings/ Implication for Maternal Health Outcome}

The results of this analysis showed that comparatively, the state shares a lot of features with the National statistics. Educational attainment shows that younger women are more likely than older women to have some education. Agriculture is the greatest employer of labour in the country and this feature is similar to that found in the state. Women participate most in agriculture than any other occupation.

The study also showed that only a handful of women are in any form of employment in the last twelve months preceding the survey. In decision making - the ability of women to make decision that affects their personal circumstances is essential for their employment. The major indication is that women take only very few decisions alone while a majority decisions are jointly made.

A woman's desire and ability to control her fertility and her choice of contraceptive methods are in part affected by her status in their household and her own sense of empowerment ${ }^{3}$. A woman who is unable to control other aspects of her life may be less able to make decision regarding her fertility. She may also feel the need to choose contraceptive methods that are less obvious or do not need the approval of her husband.

From the analysis in the present study and the National Demographic Health Survey ${ }^{3}$ - there is a positive relationship among women's empowerment and maternal health status. The study showed that increased empowerment of women is likely to increase their ability to seek and use health services to better meet their reproductive health goals, including safe motherhood. The more decisions a woman participates in, the more likely she is to have received assistance during delivery and postnatal care. The lower the number of reasons for which a woman thinks that wife beating is justified, the more likely she is to receive care form health personnel during delivery. Again, the higher the number of reasons for which a respondent believes a woman can refuse to have sex with her husband, the more likely she is to receive health care from health personnel during delivery. The same relationship is observed for the likelihood of receiving postnatal care ${ }^{3}$.

\section{Conclusions}

This study was undertaken using data from the $2008^{3}$ to examine the relationship between women empowerment and socio-economic status in order to assess the implication for maternal health outcome.

The socio-economic status was identified and the empowerment indicators were used including decision-making, justification for wife beating and decision on their earnings. All these indicators have negative health outcome of women. The study therefore concluded that there is an urgent need for an improvement in the status of women in order to be properly situated to take decisions that affect them directly. This will make them contribute to family, community and societal growth and development.

\section{Recommendations}

From the findings, the following recommendations are made:

1. There is urgent need to improve the educational attainment of women.

2. Women should be given every opportunity to take decision on issues that affect them directly.

3. There should be a communal support for maternal position in the family, community and state.

\section{REFERENCES}

[1] Nigeria Urban Reproductive Health Initiative (2009). Global Program on Family Planning and Reproductive Health, John Hopkins University

[2] Ugal, D. B. (2000). Household Environment and Maternal Health among Rural Women of Northern Cross River State, Nigeria. University of Ibadan. Unpublished Ph.D Dissertation.

[3] National Population Commission (NPC) (Nigeria) and ORC Macro 2009: Demographic and Health Survey 2008 Calverton, Maryland: NPC \& ORC Marco. 
[4] Tinker, A \& Ranson, E. (2002). The Vital Link in Saving Unborn Lives Initiatives. Population Reference Bureau
[5] World Health Organization (2007). The World Health Report: Make every mother and child Count, Geneva. 